\title{
静的地震荷重に対する単層ラチスドームの座屈耐力 BUCKLING STRENGTH OF SINGLE LAYER LATTICE DOMES UNDER STATIC SEISMIC LOAD
}

\author{
小河利行*1, 山岡幸介*2, 箕輪 健一*3, 竹内 徹*4 \\ Toshiyuki OGAWA, Kousuke YAMAOKA, Ken'ichi MINOWA \\ and Toru TAKEUCHI
}

\begin{abstract}
Although large numbers of attempts have been made to evaluate buckling strength of single layer lattice domes under equallydistributed vertical loads, stability under seismic loads has not been studied enough yet. In this paper, evaluation method on buckling strength of single layer lattice domes based on continuum shell analogy under equivalent static seismic loads proposed in the previous studies is investigated. First, the buckling behavior under distributed loads proportional to the static seismic loads is researched taking shape parameters into account. Next, the buckling strength for vertical loads and the buckling strength for static seismic loads is evaluated using continuum shell analogy, and converted to elasto-plastic buckling strength using knockdown factors and Dunkerley formulation. The effectiveness of the proposed evaluation is discussed against the results of time-history response analyses.
\end{abstract}

\begin{abstract}
Keywords : Static seismic load, Single layer lattice dome, Continuum shell analogy, Elasto-plastic buckling analysis, Buckling load factor, Incremental dynamic analysis 静的地震荷重, 単層ラチスドーム, 連続体置換, 弾塑性座屈解析, 座屈荷重係数, 動的増分解析
\end{abstract}

1. 序

単層ラチスドームは面外剛性が小さく座屈荷重が設計のクライテ リアとなるため, 座屈荷重を適切に評価することが重要である。座 屈荷重は荷重条件により異なり, 様々な荷重分布に対して研究がな されている。固定荷重や積雪荷重を想定した静的荷重に対する単層 ラチスドームの座屈荷重に関する研究の成果は文献 1-3)にまとめ られ，ラチス構造を有効剛性を用いて連続体に置換することにより 座屈荷重を推定する手法や, 特定部材の座屈応力度と正規化細長比 $\Lambda_{e}$ より単層ラチスドームの座屈荷重を推定する手法が提案されて いる。この正規化細長比に用いた評価方法の適用性については, 荷 重不整，形状初期不整等を有する場合においても検討され，複層ラ チスシェルやHP ラチスシェルのような構造物に対しても適用可能

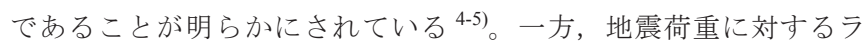
チスドームの耐力に関しては以下のような研究が挙げられる。加藤 $ら^{6)}$, 村田 ${ }^{7)}$ は鉛直および水平地震動に対する崩壊加速度について 考察している。加藤ら ${ }^{8)}$, 熊谷・小河 ${ }^{9)}$ はステップ波, 単一パルス 波のような周期特性の明確である動的荷重に対して崩壊加速度の分 析をしている。また，加藤・中澤ら ${ }^{10-12)}$ は 100 m スパンの単層ラチ スドームを対象に時刻歷応答解析により最大応答值を示す時刻での 応答加速度分布に基づき静的地震荷重を設定し, これを固定荷重に
加えて増分させた際の静的座屈荷重を時刻歴応答解析による動的座 屈荷重と比較するとともに, 修正ダンカレー式による評価を試みて いる。しかし，入力位相に依存するラチスドームの動的座屈性状は 形状規模に依存し, これらのパラメータの影響を把握することが難 しい。筆者らは文献 13) で種々のラチスドームに対して提案された 静的地震荷重 ${ }^{14-15)}$ に着目し，静的地震荷重の鉛直成分に比例した 逆対称分布荷重を受ける際の座屈性状について検討している。しか し, 上記検討は複数のパラメータを変化させて行われているものの, ドーム形状について一般化された表現とはなっていない。

そこで本研究では上記検討をより一般化し，単層ラチスドームを 対象として, 既往の研究で提案されている静的地震荷重 ${ }^{14-16)}$ に比 例した分布荷重に対する座屈耐力を連続体置換法による線形座屈荷 重から誘導することを試みる。連続体置換法による線形座屈荷重

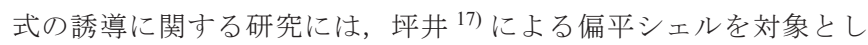
たもの, 加藤・山下ら ${ }^{18-20)}$ による 2 方向格子シェルやブレース補 剛 2 方向格子シェルを対象としたもの, 山田（聖） ${ }^{21)}$ による単層 円筒ラチスを対象としたもの，著者ら ${ }^{22-23)}$ による鞍型 HP ラチス シェルを対象としたもの等がある。しかし, これらは固定荷重を模 した鉛直等分布荷重に対して座屈荷重式を誘導したものであり，地 震荷重を模した逆対称分布荷重に対して誘導したものは見あたらな
*1 東京工業大学大学院理工学研究科建築学専攻 教授. 工博

*2 元 東京工業大学大学院理工学研究科建築学専攻 大学院生・修士(工学)

*3 東京工業大学大学院理工学研究科建築学専攻 助教・博士 (工学)

*4 東京工業大学大学院理工学研究科建築学専攻 教授・博士 (工学)
Prof., Dept. of Arch. and Building Eng., Tokyo Institute of Technology, Dr. Eng. Former Graduate Student, Dept. of Arch. and Building Eng., Tokyo Institute of Technology, M. Eng.

Assist. Prof., Dept. of Arch. and Building Eng., Tokyo Institute of Technology, Dr. Eng.

Prof., Dept. of Arch. and Building Eng., Tokyo Institute of Technology, Dr. Eng. 
い。なお通常, 構造物は地震時に固定荷重を受けている状態で地震 荷重を受けるものの，地震時の座屈荷重に対する固定荷重の影響は 常時・積雪時等の条件によっても異なる。また，これらの荷重を受 けない状態は，地震時の座屈荷重の上界になると考えられる。この ため, まずはこれらの影響を除いて座屈荷重をとらえることが研究 の端緒となる。そこで本研究では, 静的地震荷重に対する座屈に関 する第一段階の検討として, 固定荷重を受けない状態での逆対称分 布荷重による座屈性状を分析し，鉛直等分布荷重に対寸る座屈性状 との比較を行う。まず，静的地震荷重の水平成分の分布形状の違い が座屈荷重に与える影響について分析する。次に, 連続体置換法に よる線形座屈荷重の評価を行い, 幾何学的非線形性を考慮した弾性 および弾塑性座屈解析による座屈耐力との比較を行い, ノックダウ ンファクターおよび正規化細長比 $\Lambda_{e}$ を用いた修正ダンカレー式に よる換算を試みる。さらに, より簡易な評価手法として固定荷重に 対する座屈耐力と静的地震荷重に対する座屈耐力の関係の評価式を 提案し, 時刻歴応答座屈解析と比較することでその有効性を確認す る。なお, 座屈評価式の誘導は固定荷重および静的地震荷重を分離 して行うが，最終的な動的座屈解析時には固定荷重（常時）の影響 も確認する。

\section{2. 解析モデルおよび解析概要}

解析モデル 対象とする解析モデルは, 図 1 および表 1 に示寸 スパン約 $80 \mathrm{~m}$ のパラレルラメラドームである。半開角 $\theta$ は $20^{\circ}, 30^{\circ}$, $40^{\circ}$ の 3 種類とする。節点 $\mathrm{A}, \mathrm{O}, \mathrm{A}^{\prime}$ を通る円弧を稜線と呼ぶ。部材 接合部は剛接合とする。稜線上の部材長さ $l_{0}$ は $5.2 \mathrm{~m}$ とする。境界 条件は全外周節点をピン支持，または図 1 に示寸ような放射方向に 移動可能なピン・ローラー支持（以下，ローラー支持）とする。表 2 に部材諸元を示す。部材は円形鋼管とする。ラチス材は稯線上の 部材 $l_{0}$ における部材細長比 $\lambda$ が $42,56,79$ となる単一断面とする。 ラチス材の材料特性は図 3 および表 3 に示すような bi-linear 型を仮 定する。テンションリングはラチス材に対して 6 倍程度の断面積 を有するよう設定する ${ }^{24)}$ 。なお，テンションリングは弾性とする。

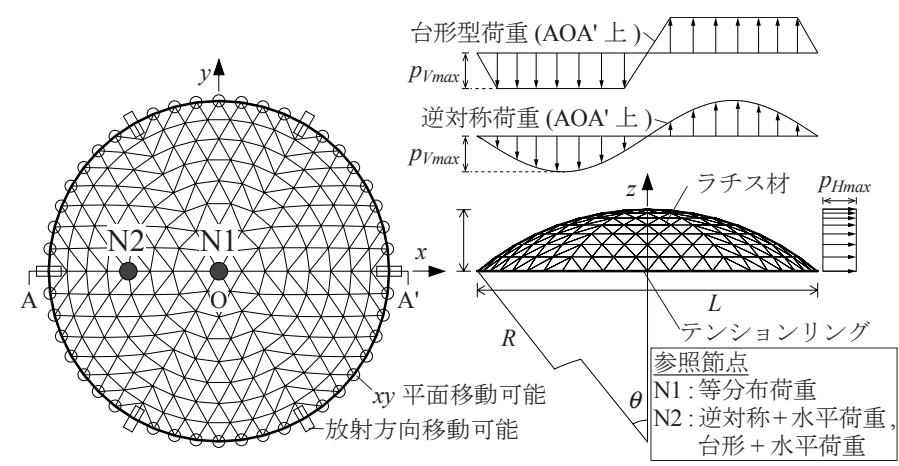

(a) 平面図 (ローラー支持, $\theta=40^{\circ}$ )

図 1 解析モデル (単層ラチスドーム)

(b) 立面図 $\left(\theta=40^{\circ}\right)$

表 1 形状諸元

\begin{tabular}{|c||c|c|c|}
\hline 半開角 $\theta\left(^{\circ}\right)$ & 20 & 30 & 40 \\
\hline \hline ドームのスパン $L(\mathrm{~cm})$ & 8153 & 7946 & 7663 \\
\hline ドームの曲率半径 $R_{D}(\mathrm{~cm})$ & 11918 & 7946 & 5961 \\
\hline ドームのライズ $H_{D}(\mathrm{~cm})$ & 719 & 1065 & 1395 \\
\hline 稜線上の部材長さ $l_{0}(\mathrm{~cm})$ & \multicolumn{3}{|c|}{520} \\
\hline
\end{tabular}

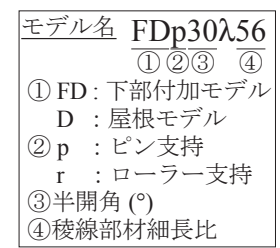

モデル名は表 1 の右に示すように，D(または FD)[ 境界条件 ][ 半開 角 $] \lambda[$ 細長比 ] と表す。なお, FD は屋根モデル (D) に下部構造を付 加したモデルである。ここで，下部構造は文献 14) と同様に，柱脚 はピン支持，柱頭とテンションリング間はピン接合とする。

解析概要 解析方法は静的座屈解析, 動的応答解析である。静的 座屈解析では, 線形固有值解析, 幾何学的非線形を考慮した弾性 および弾塑性座屈解析の 3 種類を行う。座屈解析における釣合経路 の探索には弧長増分法を用いる。動的応答解析では, モード間の 相関を考慮する CQC 法を用いた応答スペクトル解析（以下，CQC 法）と時刻歴応答解析を行う。時刻歴応答解析における数值積分法 に Newmark $\beta$ 法 $(\beta=1 / 4)$ を用い, 解析時間刻みは 1 次固有周期の約 1/100 となる 0.005 秒とする。解析モデルの減衰は Reyleigh 型とし, 減衰定数 $h$ は 1 次と 2 次のモードに対し $2 \%$ とする。部材要素は, 文献 25-27) と同様の線材要素とし, 文献 23) と同様に軸方向に 2 点, 周方向に 16 点の積分点を設け, これらの点において応力一歪み関係 の追跡および弾塑性判定を行う。ラチス材には材軸方向の中央に節 点を設け，一部材を二要素に分割することで部材座屈を考慮する。

載荷荷重 静的座屈解析での載荷荷重分布は, 固定荷重に比例し た鉛直等分布荷重または静的地震荷重に比例した分布荷重 $($ 逆対称 +水平荷重) である。静的地震荷重は半開角 $40^{\circ}$ 以下で提案された $x$ 方向水平地震動を入力時の応答加速度 ${ }^{14-15)}$ と各節点の質量の積よ り算出される荷重 (表 4) とする。なお, この荷重は下部構造を付 加した面外剛性の比較的大きなラチスドームに対して主要モードに よる応答加速度分布を正弦波型の形状で包括するように定められ， この荷重を載荷した時の部材応力は誤差はあるものの地震時の最大 応力を概ね評価できることが示されている。つまり，このような荷 重を静的に載荷することにより座屈耐力を評価することが可能であ ると考えられる。静的地震荷重の鉛直成分は, 鉛直応答増幅率 $F_{V}$ によらず図 1 に示すような正弦波 1 波型の分布形状となる逆対称荷 重である。水平成分は水平応答増幅率 $F_{H}$ により異なる分布荷重と なる (図 3)。逆対称 + 水平荷重の水平成分の最大值に対する鉛直成 分の最大值の比 $p_{V \max } / p_{H \max }$ は応答増幅率の比 $F_{V} / F_{H}$ と同值である。 図 4 に応答増幅率を示す。図に示すように水平応答増幅率 $F_{H}$ およ び応答増幅率の比 $F_{V} / F_{H}$ は周期比 $R_{T}$ に依存する。なお, 屋根部と 下部構造の共振を考慮した応答増幅率 $F_{V}{ }^{\prime}, F_{H}{ }^{\prime}$ は質量比 $R_{M}$ にも依

表 2 部材諸元

\begin{tabular}{|c|c|c|c|c|}
\hline \multicolumn{2}{|r|}{ ラチス材の部材細長比 $\lambda$} & 42 & 56 & 79 \\
\hline \multirow{4}{*}{$\begin{array}{l}\text { ラ } \\
\text { チ } \\
\text { ス } \\
\text { 材 }\end{array}$} & 外径 $d_{0}(\mathrm{~cm})$ & 35.56 & 26.74 & 19.07 \\
\hline & 厚み $t(\mathrm{~cm})$ & 0.95 & 0.70 & 0.53 \\
\hline & 断面積 $A\left(\mathrm{~cm}^{2}\right)$ & 103 & 57 & 31 \\
\hline & 断面 2 次モーメント $I\left(\mathrm{~cm}^{4}\right)$ & 15478 & 4857 & 1327 \\
\hline \multirow{4}{*}{ 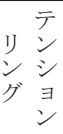 } & 外径 $d_{0}(\mathrm{~cm})$ & 70.00 & 55.00 & 40.64 \\
\hline & 厚み $t(\mathrm{~cm})$ & 3.20 & 2.20 & 1.60 \\
\hline & 断面積 $A\left(\mathrm{~cm}^{2}\right)$ & 672 & 365 & 196 \\
\hline & 断面 2 次モーメント $I\left(\mathrm{~cm}^{4}\right)$ & 375435 & 127391 & 37449 \\
\hline
\end{tabular}

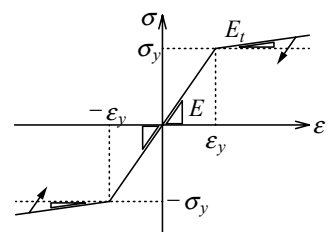

図 2 ラチス材の材料特性
表 3 材料特性

\begin{tabular}{|c|c|}
\multicolumn{1}{c}{ 表 3 材料特性 } \\
\begin{tabular}{|c|} 
ヤング係数 \\
$E\left(\mathrm{~N} / \mathrm{mm}^{2}\right)$
\end{tabular} & $2.06 \times 10^{5}$ \\
\hline $\begin{array}{c}\text { ひずみ硬化勾配 } \\
E_{t}\left(\mathrm{~N} / \mathrm{mm}^{2}\right)\end{array}$ & $2.06 \times 10^{3}$ \\
\hline $\begin{array}{c}\text { 降伏応力度 } \\
\sigma_{y}\left(\mathrm{~N} / \mathrm{mm}^{2}\right)\end{array}$ & 295 \\
\hline
\end{tabular}


存する。

また, 加藤ら ${ }^{16)}$ が提案した静的地震荷重に比例した分布荷重 ( 台 形+水平荷重) に対しても静的座屈解析を行い座屈荷重を分析する。 この分布荷重の鉛直成分は図 1 に示寸ような台形型の逆対称荷重 である（以下，台形型荷重）。なお，この台形型荷重は下部構造を 付加していない面外剛性の小さい単層ラチスドーム $\left(R_{T}=0\right.$ に相当 $)$ を対象に高次振動モードの影響も考慮することで鉛直応答加速度分 布が台形型になることに着目して定められ，半開角毎に補正係数を 設けるとともに水平荷重と鉛直荷重の位相を考慮することで地震時 の軸力分布を評価できることが示されている。

座屈荷重 鉛直分布荷重の最大值に対応した節点を参照節点と 呼ぶ。参照節点は等分布荷重においてはドーム頂部の節点 N1，逆 対称 + 水平荷重および台形 + 水平荷重においては節点 N 2 となる (図 1)。本研究では, 座屈時の参照節点における鉛直方向の荷重值 を座屈荷重と定義する。

\section{3. 水平荷重の分布形状の違いが座屈荷重に与える影響}

$x$ 方向水平地震動を受ける単層ラチスドームでは, 応答加速度の 水平成分の分布が屋根部と下部構造の周期比により異なることが既 往の研究 ${ }^{14-15)}$ で明らかにされている。図4 に示すように水平応答 増幅率 $F_{H}$ がとる範囲は 1 3 であり, 水平応答増幅率 $F_{H}$ を $1,2,3$ と した際の逆対称 + 水平荷重の水平成分は図 3 に示寸分布形状とな る。水平荷重は $F_{H}$ が 1 の場合では等分布となり， $F_{H}$ が 1 より大き い場合では節点 $\mathrm{O}$ で最大となる分布となる。そこで本章では，こ のような分布形状の差が座屈荷重に与える影響を分析する。

線形座屈性状 図 5 に逆対称荷重下または $+x$ 方向に水平荷重を 載荷した際の 1 次座屈モードを示す。水平荷重下の 1 次座屈モード は水平荷重の分布形状によらず逆対称荷重下と類似した座屈モード 形状を示す。これは, 図 6 に示す水平荷重下での軸力分布が逆対称 荷重下と同様の分布となるためである。言い換えれば， $+x$ 方向に 水平荷重を載荷した場合に, 軸力分布が逆対称荷重下と同様の分布 となるため, 静的地震荷重に対する座屈に関して危険側の位相とな る。以降, 水平荷重の載荷方向は, 文献 14-15) において提案され ているとおり $+x$ 方向とする。

弹塑性座屈荷重 逆対称 + 水平荷重の水平成分に対する鉛直成 分の比 $p_{V \max } / p_{H \max }$ が等しいものの, 水平成分の分布形状が異なる場 合（周期比 $R_{T}=0,1.25 ）$ について弾塑性座屈荷重を分析する。なお, $R_{T}=0$ は下部構造の剛性が十分高く屋根部が地震動を直接受ける状 態を, $R_{T}=1.25$ は屋根部に比べ下部構造の剛性が低く $R_{T}=0$ に比べ屋 根部が地震動を直接受けにくい状態を想定している。以下にそれぞ れの応答増幅率を示す。

$$
\begin{array}{lll}
R_{T}=0 & : F_{V}=3 C_{V} \theta, \quad F_{H}=3, \quad \text { 比 } F_{V} / F_{H}=C_{V} \theta \quad \text { (図 3(c)) } \\
R_{T}=1.25: F_{V}=C_{\nu} \theta, \quad F_{H}=1, \quad \text { 比 } F_{V} / F_{H}=C_{V} \theta \quad \text { (図 3(a)) }
\end{array}
$$

$R_{T}$ を 0 または 1.25 とした逆対称 + 水平荷重下での弾塑性座屈解 析による鉛直荷重一鉛直変位関係を図 7 に示寸。図中の $\triangle$ は初期降 伏荷重であり，最初に部材降伏が発生した時の荷重と寸る。部材降 伏は 2 章において説明した積分点が 1 点でも降伏応力度に達した場 合として定義する。図中の○は弾塑性座屈荷重であり, 荷重一変位 関係における最初の極大点となる荷重とする。荷重一変位関係は $R_{T}$ によらず同じ推移を示す。水平等分布荷重である $R_{T}=1.25$ における

\begin{tabular}{|c|c|c|}
\hline & 鉛直方向 & 水平方向 \\
\hline \begin{tabular}{l||} 
静的地震荷重 \\
$p_{V}(x, y), p_{H}(x, y)$
\end{tabular} & $m \cdot A_{e q} F_{V} \frac{x}{\sqrt{x^{2}+y^{2}}} \sin \left(\frac{2 \pi \sqrt{x^{2}+y^{2}}}{L}\right)$ & $m \cdot A_{e q}\left\{1+\left(F_{H}-1\right) \cos \left(\frac{\pi \sqrt{x^{2}+y^{2}}}{L}\right)\right.$ \\
\hline \begin{tabular}{|c||} 
静的地震荷重 \\
最大值 \\
\end{tabular} & $p_{V \max }=\left|p_{V}(-L / 4,0)\right|=m \cdot A_{e q} F_{V}$ & $p_{H \max }=p_{H}(0,0)=m \cdot A_{e q} F_{H}$ \\
\hline $\begin{array}{c}\text { 鉛直, 水平 } \\
\text { 応答増幅率 }{ }^{14)} \\
F_{V}, F_{H}\end{array}$ & $F_{V}= \begin{cases}3 C_{V} \theta & \left(0<R_{T} \leq 5 / 16\right) \\
\left(\sqrt{5 / R_{T}}-1\right) C_{V} \theta & \left(5 / 16<R_{T} \leq 5\right) \\
0 & \left(5<R_{T}\right)\end{cases}$ & $F_{H}= \begin{cases}3 & \left(0<R_{T} \leq 5 / 36\right) \\
\sqrt{5 /\left(4 R_{T}\right)} & \left(5 / 36<R_{T} \leq 5 / 4\right) \\
1 & \left(5 / 4<R_{T}\right)\end{cases}$ \\
\hline \begin{tabular}{l||} 
応答増幅率 ${ }^{15)}$ \\
修正 $F_{V^{\prime}}, F_{H}{ }^{\prime}$
\end{tabular} & $F_{V}^{\prime}=\sqrt{F_{V}^{2}+\frac{1}{\left(1-R_{T}^{2}\right)^{2}+\left(1 / R_{M}^{\prime}\right)}}$ & $F_{H}{ }^{\prime}=\sqrt{F_{H}^{2}+\frac{1}{\left(1-R_{T}^{2}\right)^{2}+\left(1 / R_{M}^{\prime}\right)^{\theta}}}$ \\
\hline
\end{tabular}

表 4 静的地震荷重 ${ }^{14-15)}$ (逆対称 + 水平荷重)

$A_{e q}$ : 等価 1 質点系の応答加速度, $x, y$ : ドーム頂部を原点とする $x y$ 座標, $F_{V}, F_{H}$ : 鉛直, 水平応答増幅率, $F_{V}^{\prime}, F_{H}{ }^{\prime}$ : 屋根部と下部構造の共振を考慮した鉛直, 水平応答増幅率の修正値, $T_{R}$ : 屋根部の逆対称 1 波型の振動モードの固有周期, $T_{e q}$ : 等価 1 質点系の固有周期, $R_{T}$ : 周期比 $\left(R_{T}=T_{e q} / T_{R}\right), M_{R}$ : 屋根部の質量, $M_{e q}$ : 等価 1 質点系の質量, $M_{R}{ }^{\prime}$ : 振動に関与する屋根部の質量 $\left(M_{R}{ }^{\prime}=0.55 \cdot M_{R}\right)$, $R_{M}:$ 質量比 $\left(R_{M}=M_{e q} / M_{R}\right), C_{V}$ : 係数 $\left(C_{V}=1.85\right), \theta$ : 半開角 $(\mathrm{rad})$

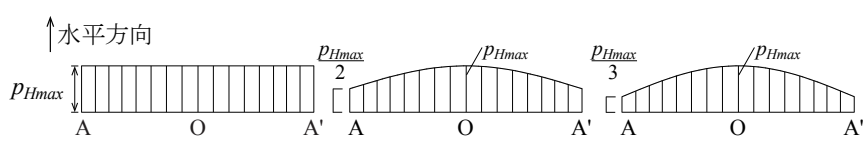

(a) 水平応答増幅率 $F_{H}=1 \quad$ (b) 水平応答増幅率 $F_{H}=2 \quad$ (c) 水平応答増幅率 $F_{H}=3$ 図 3 逆対称 + 水平荷重の水平成分の分布形状 (稜線 $A O A^{\prime}$ 上 )

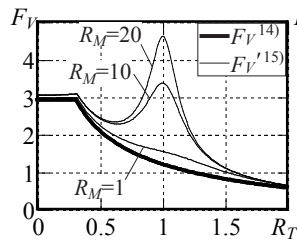

(a) 鉛直応答増幅率 $F_{V}$

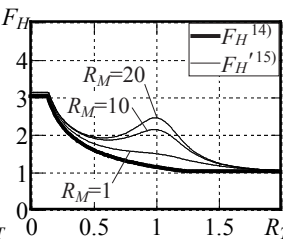

$\begin{array}{ll}\text { (b) 水平応答増幅率 } F_{H} & \text { (c) 応答増幅率の比 } F_{V} / F_{H}\end{array}$ 4 応答増幅率 ${ }^{14-15)}\left(\right.$ 半開角 $\theta=30^{\circ}$ )

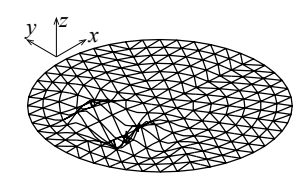

(i) アイソメ

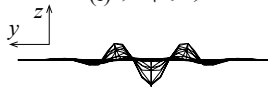

(ii) 立面図

(a) 逆対称荷重 (i) アイソメ

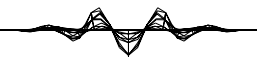

(ii) 立面図

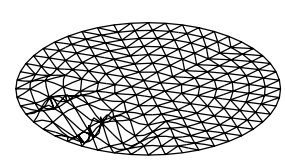

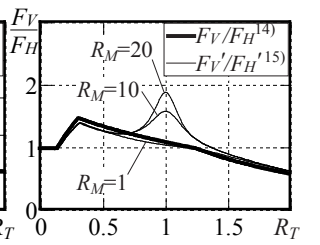

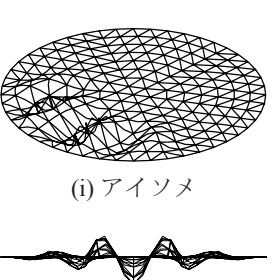

(ii) 立面図

図 51 次座屈モード（線形座屈時, Dp30ᄉ56)

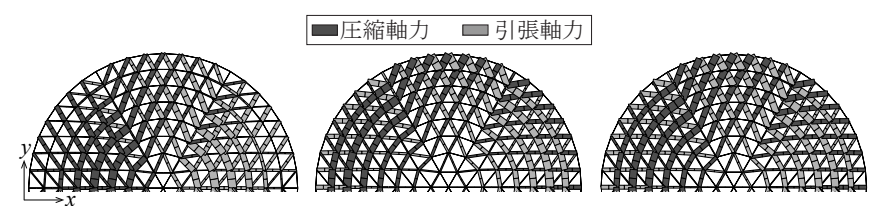

(a) 逆対称荷重

(b) 水平荷重 $\left(F_{H}=1\right)$

図 6 軸力分布（線形座屈時, Dp30入56)

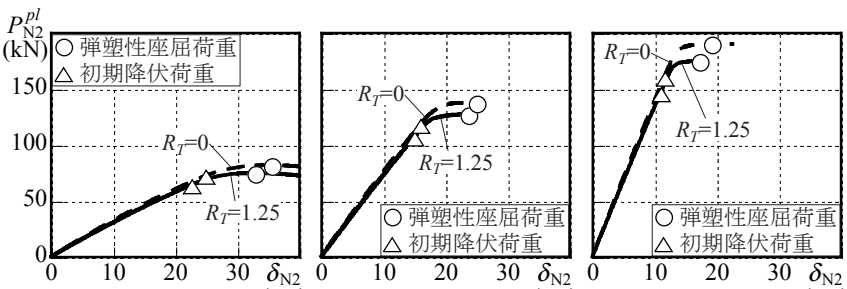

$\begin{array}{lllll}\text { (a) } \operatorname{Dp} 20 \lambda 56 & \text { (cm) } & \text { (b) } D p 30 \lambda 56 & \text { (cm) } & \text { (c) } D p 40 \lambda 56 \quad(\mathrm{~cm})\end{array}$

図 7 鉛直荷重 - 鉛直変位関係 (逆対称 + 水平荷重 $\left(R_{T}=0,1.25\right)$, 弾塑性座屈解析) 
弾塑性座屈荷重は等分布でない $R_{T}=0$ に比べて若干小さい值となり, 水平荷重の分布形状が座屈荷重に与える影響は小さい。そこで以降 では, 逆対称 + 水平荷重および台形 + 水平荷重の水平成分は水平 等分布荷重として扱う。

\section{4. 静的地震荷重に比例した分布荷重に対する座屈性状}

応答増幅率の比 $F_{V} / F_{H}\left(=p_{V \max } / p_{H \max }\right)$ は, 図 4(c) に示すように, 屋根部と下部構造の周期比により $0 \sim 2$ 程度の範囲をとる。このため, 対象とする単層ラチスドームを包括的に分析するために, 逆対称 + 水平荷重および台形 + 水平荷重の水平成分と鉛直成分の大きさの 関係について以下に示すようなパラメータを設ける。

$$
p_{\text {Vmax }}: p_{\text {Hmax }}=1: 0,1: 0.3,1: 0.5,1: 1,1: 2
$$

\section{1. 単層ラチスドームの線形座屈荷重評価}

\subsection{1. 連続体置換法による線形座屈荷重式の導出}

本研究で扱う分布荷重を受ける単層ラチスドームの線形座屈荷重 を連続体置換法により導出する。ここでは，ドーム形状を次式で表 し, ねじり率 $\partial^{2} z / \partial x \partial y$ が 0 である EP シェル形状で近似する。

$$
z=-x^{2} /(2 R)-y^{2} /(2 R)
$$

ここに, $x, y, z$ は $x y z$ 座標, $R$ は曲率半径である。

文献 17-23) と同様に，シェルが偏平であると仮定して微分方程式 の固有值として座屈荷重式を導出する。微小要素における釣り合い 式(式 (2)), ひずみと変位の関係式 (式 (3)), 応力とひずみ, 曲げ およびねじりモーメントと変位の関係式 (式 (4)) を示す。

$$
\begin{aligned}
& \left\{\begin{array}{l}
\frac{\partial N_{x}}{\partial x}+\frac{\partial N_{x y}}{\partial y}+X=0, \frac{\partial N_{y}}{\partial y}+\frac{\partial N_{x y}}{\partial x}+Y=0 \\
\frac{\partial^{2} M_{x}}{\partial x^{2}}+2 \frac{\partial^{2} M_{x y}}{\partial x \partial y}+\frac{\partial^{2} M_{y}}{\partial y^{2}}+N_{x} k_{x}+N_{y} k_{y} \\
+\frac{\partial}{\partial x}\left(N_{x} \frac{\partial w}{\partial x}\right)+\frac{\partial}{\partial y}\left(N_{x y} \frac{\partial w}{\partial x}\right)+\frac{\partial}{\partial x}\left(N_{x y} \frac{\partial w}{\partial y}\right)+\frac{\partial}{\partial y}\left(N_{y} \frac{\partial w}{\partial y}\right)+Z=0
\end{array}\right. \\
& \left\{\begin{array}{l}
\varepsilon_{x}=\frac{\partial u}{\partial x}-k_{x} w, \varepsilon_{y}=\frac{\partial v}{\partial y}-k_{y} w, \gamma_{x y}=\frac{\partial v}{\partial x}+\frac{\partial u}{\partial y} \\
M_{x}=-D\left(\frac{\partial^{2} w}{\partial x^{2}}+v \frac{\partial^{2} w}{\partial y^{2}}\right), N_{y}=-D\left(\frac{\partial^{2} w}{\partial y^{2}}+v \frac{\partial^{2} w}{\partial x^{2}}\right), M_{x y}=-D_{x y} \frac{\partial^{2} w}{\partial x \partial y}
\end{array}\right.
\end{aligned}
$$

ここに, $X, Y, Z$ は $x, y, z$ 方向に対する外圧力, $u, v, w$ は $x, y, z$ 方向に 対する変位, $\varepsilon_{x}, \varepsilon_{y}$ は $x, y$ 方向のひずみ, $\gamma_{x y}$ はせん断ひずみ, $N, N_{x y}$

\begin{tabular}{|c|c|c|c|c|}
\hline 座屈前 & & 座屈後 & 座屈前 & \\
\hline$N_{x 0}$ & $\rightarrow$ & $N_{x 0}+N_{x}$ & $M_{x 0}(=0)$ & $\rightarrow$ \\
\hline$N_{y 0}$ & $\rightarrow$ & $N_{y 0}+N_{y}$ & $M_{y 0}(=0)$ & $\rightarrow$ \\
\hline$N_{x y 0}(=0)$ & $\rightarrow$ & $N_{x y}$ & $M_{x y 0}(=0)$ & $\rightarrow$ \\
\hline
\end{tabular}
$M, M_{x y}$ はそれぞれ軸応力, せん断応力, 曲げモーメント, ねじりモー メント, $K, K_{x y} D, D_{x y}$ はそれぞれ板の伸び剛性, せん断剛性, 曲げ 剛性, 漦じり剛性, $v$ はポアソン比, $k_{x}, k_{y}$ は曲率 $\partial^{2} z \partial x^{2}, \partial^{2} z \partial y^{2}$ である。 なお, 座屈前は完全な膜応力状態が成立していると仮定し, 膜応力 による変形は座屈による変形に比べ非常に小さく, 座屈前後におい て微小要素に作用する各応力は次のように変化すると仮定する。

式 (2)より座屈前後の釣り合いの方程式をたて, 座屈により生じる 応力の応力関数 $\phi$ を次式で定義する。

$$
N_{x}=\frac{\partial^{2} \phi}{\partial y^{2}}, N_{x y}=-\frac{\partial^{2} \phi}{\partial x \partial y}, N_{y}=\frac{\partial^{2} \phi}{\partial x^{2}}
$$

式 (3)より求まる適合条件式と座屈前後の釣り合い方程式より次式 を得る。

$\left\{\frac{1}{\bar{K}} \frac{\partial^{4}}{\partial x^{4}}+\frac{1}{\bar{K}} \frac{\partial^{4}}{\partial y^{4}}+\left(\frac{1}{K_{x y}}-\frac{2 v}{\bar{K}}\right) \frac{\partial^{4}}{\partial^{2} x \partial^{2} y}\right\}\left(-N_{x 0} \frac{\partial^{2}}{\partial x^{2}}-N_{y 0} \frac{\partial^{2}}{\partial y^{2}}\right) w$

$+\left\{\frac{1}{K} \frac{\partial^{4}}{\partial x^{4}}+\frac{1}{K} \frac{\partial^{4}}{\partial y^{4}}+\left(\frac{1}{K_{x y}}-\frac{2 v}{\bar{K}}\right) \frac{\partial^{4}}{\partial^{2} x \partial^{2} y}\right\}\left\{D\left(\frac{\partial^{4}}{\partial x^{4}}+\frac{\partial^{4}}{\partial y^{4}}\right)+2\left(D v+D_{x y}\right) \frac{\partial^{4}}{\partial x^{2} \partial y^{2}}\right\} w$

$+\left\{k_{x} \frac{\partial^{2}}{\partial y^{2}}+k_{y} \frac{\partial^{2}}{\partial x^{2}}\right\}^{2} w=0$

ここに， $\bar{K}=\left(1-v^{2}\right) K$ である。

座屈モード $w$ は, 座屈荷重式の算出が容易な上に安全側の評価と なるように，境界条件を周辺単純支持として式 (7) により仮定する。

$$
w=B_{m n} \sin \left\{m^{\prime} \pi\left(x+L_{x} / 2\right) / L_{x}\right\} \sin \left\{n^{\prime} \pi\left(y+L_{y} / 2\right) / L_{y}\right\}
$$

ここに, $m^{\prime}, n^{\prime}$ は $x, y$ 方向の座屈モードの半波の個数, $L_{x}, L_{y}$ は $x, y$ 方向のスパンである。

ここで, 外圧力と膜応力の関係を示す。本研究で扱う鉛直外圧力 $p_{V}$ に対する座屈前の応力は, $p_{V}$ による曲げ応力が局所荷重の場合 のようには大きくないと考えられるため，文献 17) を参考に鉛直荷 重の分布を局所的に等分布な荷重と近似して, 次式で表される $p_{V}$ と同様の分布を有する膜応力として仮定する。

$N_{x 0}{ }^{\prime}(x, y)=p_{V}(x, y) \frac{k_{x}+v k_{y}}{k_{x}^{2}+2 v k_{x} k_{y}+k_{y}^{2}}, N_{y 0}{ }^{\prime}(x, y)=p_{V}(x, y) \frac{k_{y}+v k_{x}}{k_{y}^{2}+2 v k_{y} k_{x}+k_{x}^{2}}$

なお, これらの応力 $N_{x 0}{ }^{\prime}, N_{y 0}{ }^{\prime}$ の分布は, 図 6 (a) に示寸軸力分布と 概衫良い対応を示す。また，水平外圧力 $p_{H}$ （等分布）に対する座 屈前の応力は, 周辺ピン支持の場合を想定し, 式 (2)を満たすよう に次式で表現する。

$N_{x 0}{ }^{\prime \prime}(x, y)=-p_{H} x, N_{y 0} "(x, y)=-\frac{k_{x}}{k_{y}} N_{x 0} "=\frac{k_{x}}{k_{y}} p_{H} x$

ここに, $L$ はドームのスパンであり $, x, y$ の領域はドーム頂点を原 点とし $-L / 2$ から $L / 2$ とする。

なお，本研究のローラー支持もテンションリングの存在のために周 辺ピン支持の条件に近いと考えられる。次に, ドームの面外剛性 が小さいことと図 6 に示すように水平荷重下の軸力分布が逆対称荷 重下と類似した分布であることを考慮して，応力 $N_{x 0}{ }^{\prime}, N_{x 0}{ }^{\prime \prime}$ および $N_{y 0}{ }^{\prime}, N_{y 0}{ }^{\prime \prime}$ を逆対称荷重が最大となる位置 $((x, y)=(-L / 4,0))$ で重社合 わせる。

$$
\begin{aligned}
& N_{x 0}=-p_{V \max }\left(\frac{k_{x}+v k_{y}}{k_{x}^{2}+2 v k_{x} k_{y}+k_{y}^{2}}-\frac{p_{H \max }}{p_{V \max }} \frac{L_{x}}{4}\right), \\
& N_{y 0}=-p_{V \max }\left(\frac{k_{y}+v k_{x}}{k_{y}^{2}+2 v k_{y} k_{x}+k_{x}^{2}}+\frac{k_{x}}{k_{y}} \frac{p_{H \max }}{p_{V \max }} \frac{L_{x}}{4}\right)
\end{aligned}
$$

ここに, $p_{\text {Vmax }}, p_{H \max }$ は $p_{V}(x, y), p_{H}(x, y)$ の最大值であり,$p_{H \max } / p_{\text {Vmax }}$ はモデルの半開角および周期比により定まる定数である。

式 (6) (10)より，線形座屈荷重式は次式で表せる。

表 5 有効剛性 (等方性) 3,18-19,28)

\begin{tabular}{|c|c|c|c|c|}
\hline 伸び剛性 $K$ & せん断剛性 $K_{x y}$ & 曲げ剛性 $D$ & ねじり剛性 $D_{x y}$ & ポアソン比 $v$ \\
\hline \hline$\frac{E_{e} t_{e}}{\left(1-v^{2}\right)}$ & $\frac{E_{e} t_{e}}{2(1+v)}$ & $\frac{E_{e} t_{e}^{3}}{12\left(1-v^{2}\right)}$ & $\frac{E_{e} t_{e}^{3}}{12(1+v)}$ & $1 / 3$ \\
\hline
\end{tabular}

$E_{e}$ : 等価ヤング係数 $\left(E_{e}=E A /\left(3 l_{0} r_{g}\right)\right), t_{e}$ : 等価シェル厚 $\left(t_{e}=2 \sqrt{3} r_{g}\right)$ $r_{g}$ : ラチス材の断面 2 次半径 $\left(r_{g}=\sqrt{I / A}\right), E$ : ラチス材のヤング係数 $A$ : ラチス材の断面積, $I$ : ラチス材の断面 2 次モーメント, $l_{0}$ ：ラチス材の基準長さ 


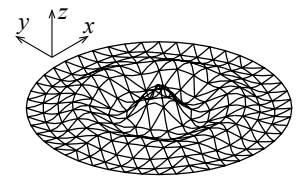

(i) アイソメ

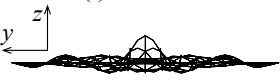

(ii) 立面図

(a) $\mathrm{Dp} 30 \lambda 42$

(A) 等分布荷重

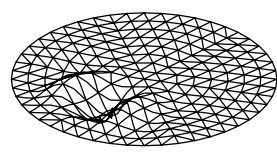

(i) アイソメ

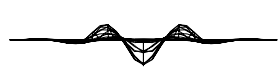

(ii) 立面図

(a) $\mathrm{Dp} 20 \lambda 56$

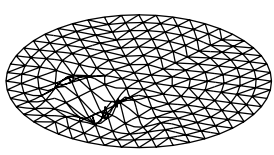

(i) アイソメ

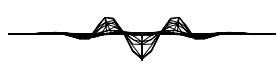

(ii) 立面図

(b) $\operatorname{Dp} 30 \lambda 56$

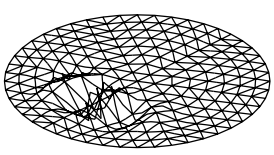

(i) アイソメ

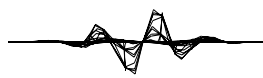

(ii) 立面図

(c) $\mathrm{Dp} 40 \lambda 56$

(B) 逆対称荷重 $\left(p_{V \max }: p_{H \max }=1: 0\right)$

図 8 1 次座屈モード（線形座屈時）

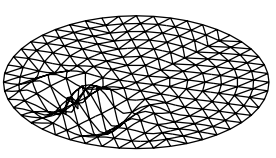

(i) アイソメ

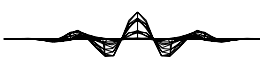

(ii) 立面図

(a) $\operatorname{Dp} 30 \lambda 56$

(i) アイソメ

(a) $\operatorname{Dp} 30 \lambda 56$

(C) 逆対称 + 水平荷重 $(1: 1) \mid$ (D) 台形 + 水平荷重 $(1: 1)$

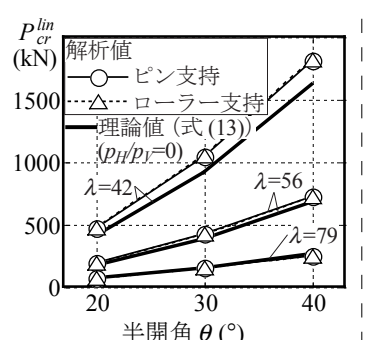

(A) 等分布荷重 $($ 節点 $\mathrm{N} 1$ )

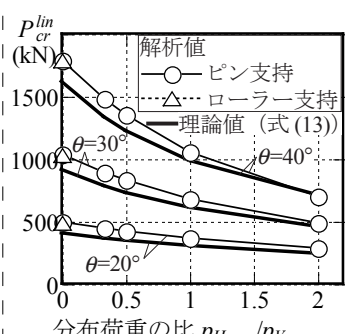

(B) 逆対称 +水平花重 $(\lambda=42, \mathrm{~N} 2$

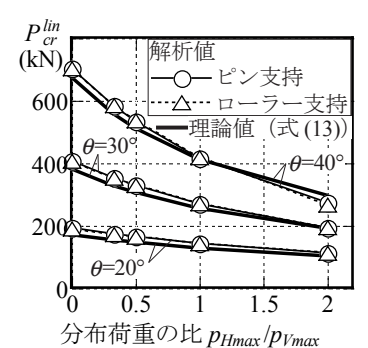

分布荷重の比 $p_{H \max } / p_{V \max }$

図 9 線形座屈荷重

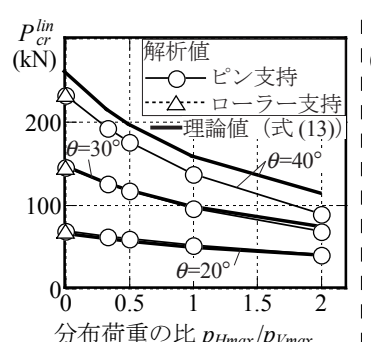

(D) 逆対称 + 水平荷重 $(\lambda=79$,

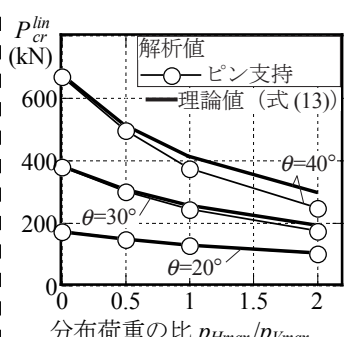

公台形十水平花重 $(\lambda=56, \mathrm{~N} 2)$

$$
\begin{aligned}
& P_{c r}^{l i n}=A_{\text {node }} \frac{k_{x}^{2}+2 v k_{x} k_{y}+k_{y}^{2}}{k_{x}+v k_{y}} \frac{1}{\left\{1+c_{m n}^{2} \frac{k_{y}+v k_{x}}{k_{x}+v k_{y}}+\left(\frac{k_{x}}{k_{y}} c_{\text {mn }}^{2}-1\right) \frac{p_{\text {thax }}}{p_{\text {Imax }}} \frac{L}{4} \cdot \frac{k_{x}^{2}+2 v k_{x} k_{y}+k_{y}^{2}}{k_{x}+v k_{y}}\right\}} \\
& \times\left\{\left\{D\left(1+c_{m n}^{4}\right)+2\left(D v+D_{x y}\right) c_{m n}^{2}\right\}\left(\frac{m^{\prime} \pi}{L_{x}}\right)^{2}+\frac{\left\{k_{x} c_{m n}^{2}+k_{y}\right\}^{2}}{\left\{\frac{1-2 v c_{m n}^{2}+c_{m n}^{4}}{K\left(1-v^{2}\right)}+\frac{c_{m n}^{2}}{K_{x y}}\right\}}\left(\frac{m^{\prime} \pi}{L_{x}}\right)^{-2}\right\}
\end{aligned}
$$

ここに， $A_{n o d e}$ は節点あたりの支配面積， $c_{m n}=\left(n^{\prime} / L_{y}\right) /\left(m^{\prime} / L_{x}\right)$ である。

ここで, 式 (11)の 2 行目に相加相乗平均の関係を用い, 表 5 で表 される有効剛性 3,18-19,28) を代入すると, 線形座屈荷重式は次式で表 される。

$P_{c r}^{l i n}=A_{\text {node }} \frac{1+c_{m n}^{2}}{1+c_{m n}^{2}+\left(c_{\text {mn }}^{2}-1\right)\left(p_{\text {Hmax }} / p_{\text {Vmax }}\right) \sin \theta} \cdot \frac{2 \sqrt{6} E A}{\left(l_{0} / r_{g}\right) R^{2}}$

ここに, $\theta$ は半開角 $(\mathrm{rad})$ である。

さらに, 静的地震荷重の場合には $c_{m n}$ が 0 より大きい值から無限大 までをとることを考慮して式(12)の下界を抑えると, 線形座屈荷 重式は次式で表される。

$P_{c r}^{l i n}=A_{\text {node }} \frac{1}{1+\left(p_{\text {Hmax }} / p_{\text {Vmax }}\right) \sin \theta} \cdot \frac{2 \sqrt{6} E A}{\left(l_{0} / r_{g}\right) R^{2}}$

なお，これは等分布荷重下においても成立する式である。ただし， 等分布荷重下において下限值を与える $c_{m n}$ は 1.0 である。一方, 静 的地震荷重下の場合, 式 (11) の下界を抑える過程に伴い, 座屈モ一 ドの半波数 $n^{\prime}$ は式 (12)の極小值をとる $c_{m n}$ から無限大になると推 測でき, $m^{\prime}$ は相加相乗平均の等号が成り立つ場合の条件から推測 できる。しかし, 式 $(10)$ による座屈前の応力は逆対称荷重が最大 となる位置 $((x, y)=(-L / 4,0))$ でのみしか成り立っていないため, こ のときの半波数 $m^{\prime}, n^{\prime}$ は実際の座屈モードと対応しない。なお，パ ラレルラメラドームの各節点あたりの支配面積 $A_{\text {node }}$ は $\sqrt{3} l_{0}^{2} / 2$ とする ${ }^{3)}$ 。 また以降では, 式 (13) より算出される座屈荷重を理論值と呼ぶ。

\subsection{2. 線形座屈モードの分析}

本項では線形座屈モードを分析する。図 8 に線形固有值解析にお ける 1 次座屈モードを示す。等分布荷重下での 1 次座屈モードは全

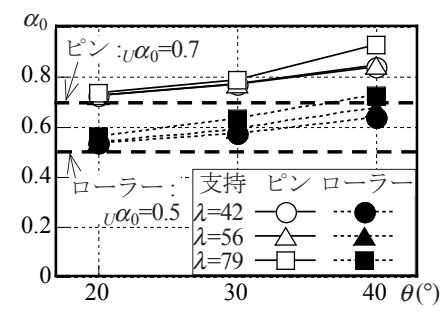

(A) 等分布荷重

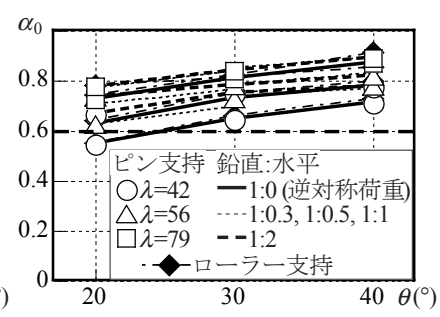

(B) 逆対称 + 水平荷重
図 10 ノックダウンファクター $\alpha_{0}$

体に変位が見られ，概ねのモデルにおいてモード形状は頂点を中心 に同心円状に変位の見られる全体座屈モードを呈する。一方，逆対 称荷重, 逆対称 + 水平荷重および台形 + 水平荷重下では鉛直下向 き荷重を受ける部分に変位が見られ, $y$ 方向に座屈半波数を複数持 つモード形状を呈する。このとき, 変位の大きい $y$ 方向の座屈半波 数は $3 \sim 5$ 程度であり, $x$ 方向の座屈半波長に比べ $y$ 方向の座屈半波 長は短い。なお, パラレルラメラドームでの逆対称荷重下での座屈 モード形状は 3 方向グリッドドーム ${ }^{13)}$ と同様の形状となる。

図 9 に参照節点での線形座屈荷重 $P_{c r}^{l i n}$ を示す。各分布荷重下での 線形座屈荷重は, 半開角が大きく, 細長比が小さくなるに伴い大き くなる。同一モデルにおいて各分布荷重下での線形座屈荷重を比較 すると, 等分布荷重, 逆対称荷重および台形型荷重下で概袘しい ことがわかる。また, 逆対称 +水平荷重および台形 +水平荷重下 での線形座屈荷重は分布荷重の水平成分が鉛直成分に比べ大きくな るに伴い低下する。なお, 各分布荷重下での線形座屈荷重は式 (13) より算出される理論值と概ねよい対応を示す。

\section{2. 単層ラチスドームの弾性および弾塑性座屈荷重}

\section{2. 1. 单層ラチスドームの弾性座屈荷重}

線形座屈荷重に対する弾性座屈荷重の比 $\alpha_{0}$ (ノックダウンファ クター)を分析する。図 10 に各荷重下でのノックダウンファクター $\alpha_{0}$ を示す。各荷重下でのノックダウンファクターは半開角および 細長比が小さくなるに伴い小さくなる。ピン支持の場合, ノックダ ウンファクターの最小值は等分布荷重下で 0.7 , 逆対称 + 水平荷重 
下で 0.6 程度であり, 後者の方が幾何学的非線形性の影響を受けや 寸い。なお，時刻歴応答解析において最大応答值を示寸時刻での応 答加速度分布に基づく静的地震荷重について同様な検討をしている 文献 11-12)の結果と比較すると，ほぼ同様な傾向を示すものの 0.5 程度と少し值が小さい。これは, 本研究では固定荷重の影響を考慮 していないことが影響していると考えられる。一方，ローラー支持 の場合, 逆対称＋水平荷重下ではピン支持モデルと同程度であるが, 等分布荷重下では 0.5 程度に低下寸るため，等分布荷重下の方が幾 何学的非線形性の影響を受けや寸い。なお，逆対称＋水平荷重下で のノックダウンファクターは逆対称荷重下に比べ若干大きくなる。

\section{2. 2. 単層ラチスドームの弾塑性座屈荷重}

図 11 に弾塑性座屈解析による参照節点での鉛直荷重-鉛直変位関 係を示す。逆対称 + 水平荷重および台形 + 水平荷重下での荷重-変 位関係は，分布荷重の水平成分が鉛直成分に比べ大きくなるに伴い 勾配が緩やかになり, 弾塑性座屈荷重が低下寸る。また，半開角が 大きくなるに伴い水平荷重による弾塑性座屈荷重の低下量が大きく なる。これは, 半開角が大きくなるに伴い水平荷重がシェルに対し て面外方向に作用寸るために水平荷重による座屈荷重一影響が大き くなるためである。なお，このためライズの高いドームに対して線 形座屈荷重式を導出する際には水平荷重を面内と面外成分に分割す る必要があると考えられる。逆対称 + 水平荷重下での荷重-変位関 係は初期降伏荷重後も荷重および変位は増加する。一方, 台形 + 水 平荷重下での初期降伏後の荷重一変位関係は分布荷重の水平成分が 鉛直成分に比べ大きくなるに伴い変位が減少する方向に推移する。 そのため, 逆対称 + 水平荷重下に比べ弾塑性座屈時の変位は小さい。 弾塑性座屈時の変位量をドームスパン $L$ に対する変位としてみると 概ね 1/250 以下である。耐震性能を論じる上では，限界変形を考慮 する必要があると考えられるが，中澤らによる単層ラチスドームの 耐震性能評価の研究 ${ }^{29-30)}$ において重要な指標と考えられているス パン $L$ の $1 / 250$ という基準より変形が概补小さいため, 本研究では 限界変形について詳しい分析は行わない。図には示していないが, ローラー支持モデルでの逆対称＋水平荷重下での荷重-変位関係は ピン支持モデルとほぼ同様の推移となり, ピン支持モデルと同程度 の弾塑性座屈荷重を有する。

図 12 に弾塑性座屈時までの逆対称 + 水平荷重下における部材降 伏過程を示す。部材降伏は稜線に接合されるリング状の部材より発 生する。分布荷重の水平成分が鉛直成分に比べ大きくなるに伴い部 材降伏数が増大し, 図 12(B) のので示す位置にも部材降伏が発生す る。図には示していないが，これらの特徴は台形＋水平荷重下で も見られる。

\section{2. 3. 形状初期不整を有するモデルに対する座屈荷重}

ピン支持で細長比 56 で構成されたモデルを対象に逆対称 + 水平 荷重下での形状初期不整の影響について分析する。既往の研究 ${ }^{2-3,5)}$ にならい, 形状初期不整は等分布荷重下における 1 次座屈モードと 相似な形状とし, 最大不整振幅 $d_{0}$ は等価シェル厚 $t_{e}$ の 0.2 倍とする。

図 13 に弾塑性座屈解析による参照節点の鉛直荷重-鉛直変位関係 を示す。等分布荷重下では, 初期不整を有するモデルの荷重一変位 関係における初期降伏までの勾配は完全形状のモデルのそれに比べ 小さく, 弾塑性座屈荷重も小さい。一方, 逆対称荷重下では完全形 状とほぼ同じ推移となり, 同程度の弾塑性座屈荷重を有する。また,
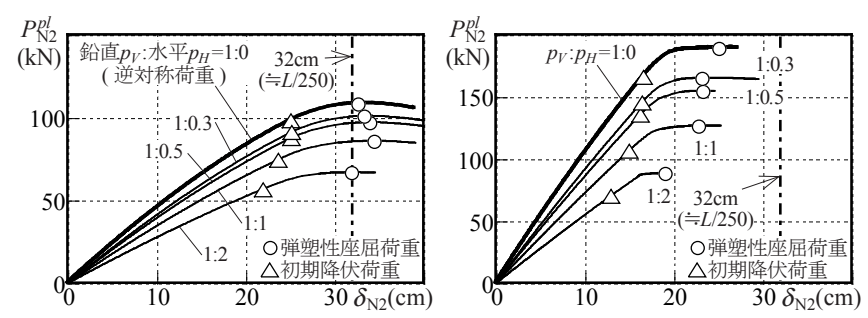

(A1) 逆対称 + 水平荷重 $\left(\theta=20^{\circ}\right.$, 節点 $\left.\mathrm{N} 2\right)$

(A2) 逆対称 + 水平荷重 $\left(\theta=30^{\circ}\right.$, 節点 $\left.\mathrm{N} 2\right)$
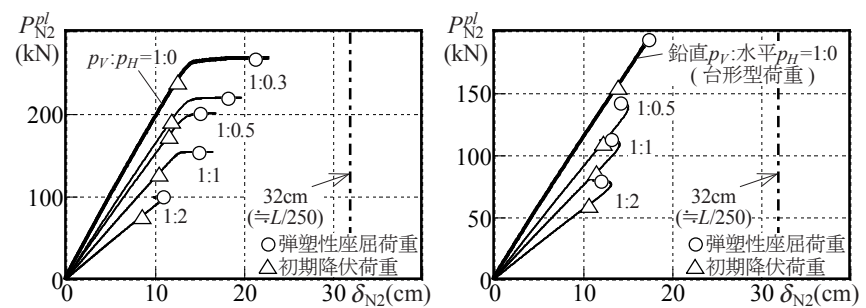

(A3) 逆対称十水平荷重 $\left(\theta=40^{\circ}\right.$, 節点 $\left.\mathrm{N} 2\right) \quad(\mathrm{B} 1)$ 台形 + 水平荷重 $\left(\theta=30^{\circ}\right.$, 節点 $\left.\mathrm{N} 2\right)$

図 11 鉛直荷重 - 鉛直変位関係（弾塑性座屈解析, 細長比 56)

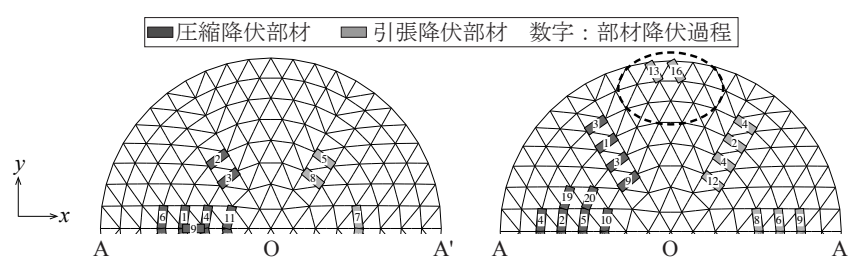

(A) 逆対称荷重

(B) 逆対称 + 水平荷重 $(1: 1)$

図 12 部材降伏過程（弾塑性座屈時まで, Dp30入56）

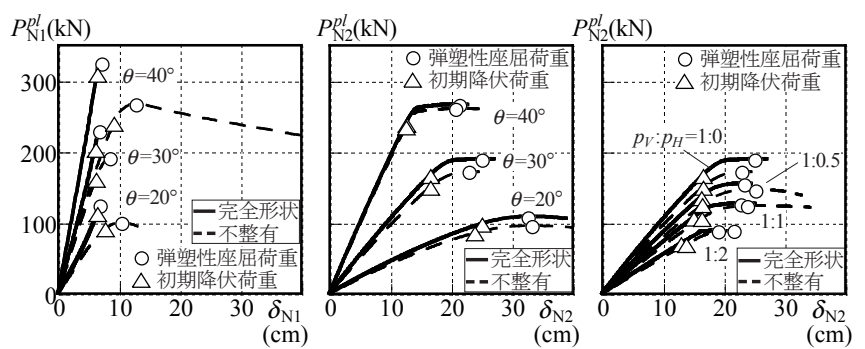

(A) 等分布荷重 ( 節点 $\mathrm{N} 1)$ (B) 逆対称荷重 $(\mathrm{N} 2)$ (C) 逆対称+水平荷重 $\left(\theta=30^{\circ}, \mathrm{N} 2\right)$

図 13 鉛直荷重 - 鉛直変位関係（弾塑性座屈解析，形状初期不整有り， $\lambda=56$ )

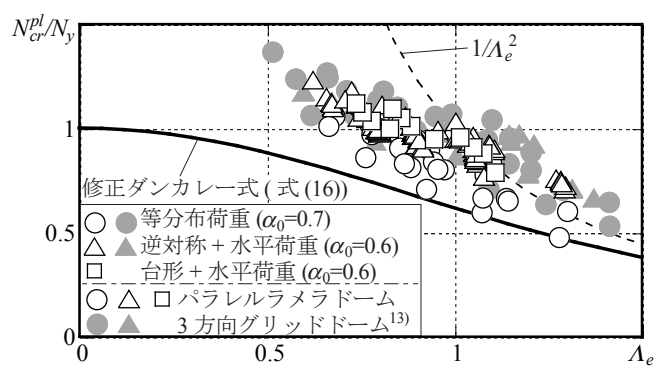

図 14 修正ダンカレー式による弾塑性座屈荷重の評価

逆対称 + 水平荷重下でも完全形状と同様の推移となる。

\section{5. 弾塑性座屈荷重の評価}

\section{1. 修正ダンカレー式による弾塑性座屈荷重の評価}

既往の研究 2-3,13) において単層ラチスドームを対象として用いら れる正規化細長比 $\Lambda_{e}$ を用いた修正ダンカレー式による評価法を本 研究においても援用する。正規化細長比 $\Lambda_{e}$ は次式で与えられる。

$$
\Lambda_{e}=\sqrt{N_{y} /\left(\alpha_{0} \cdot N_{c r}^{l i n}\right)}
$$

ここに, $N_{y}$ は降伏軸力, $N_{c r}^{l i n}$ は線形座屈解析において最大圧縮応力 
度を示寸部材の線形座屈軸力, $\alpha_{0}$ はノックダウンファクターである。

図 14 に正規化細長比 $\Lambda_{e}$ による軸力に換算した弾塑性座屈荷重の 評価を示す。縦軸は座屈軸力 $N_{c r}^{p l}$ を降伏軸力で無次元化したもので ある。 $N_{c r}^{p l}$ は次式で与えられる座屈軸力である。

$$
N_{c r}^{p l}=\left(N_{0} / P_{0}\right) \cdot P_{c r}^{p l}
$$

ここに, $N_{0}$ は微小変形仮定のもとで, 単位荷重 $P_{0}$ に対して計算され る最大圧縮応力度を示寸部材の軸力, $P_{c r}^{p l}$ は弾塑性座屈荷重である。 図中に示寸修正ダンカレー式は次式で与えられる。

$$
\Lambda_{e}^{2}\left(N_{c r}^{p l} / N_{y}\right)+\left(N_{c r}^{p l} / N_{y}\right)^{2}=1.0
$$

各分布荷重下において修正ダンカレー式が弾塑性座屈荷重の下限值 となり，安全側に評価できる。ここで，ノックダウンファクター $\alpha_{0}$ は，ピン支持，ローラー支持の両場合ともに，本研究では図 10 より等分布荷重下で 0.7 , 逆対称 + 水平荷重および台形 + 水平荷重 下で 0.6 とする。なお, ローラー支持の場合, 等分布荷重下でのノッ クダウンファクターは 0.5 程度であるものの, ピン支持同様に 0.7 としても安全側に評価可能である。ただし，初期不整を考慮した場 合には文献 2) に示されているように 0.5 を用いる必要があると考え られる。また，時刻歴応答解析において最大応答值を示寸時刻での 応答加速度分布に基づく静的地震荷重について検討した文献 11-12) においても，ノックダウンファクターは 0.5 程度で評価できている。 ただし，この值は本研究における逆対称＋水平荷重および台形 + 水平荷重下に用いた 0.6 に比べ小さい。このため, 固定荷重を考慮 した場合，ノックダウンファクターには 0.5 程度の值を用いる必要 があると考えられる。

\section{2. 連続体置換法による座屈荷重係数の評価}

修正ダンカレー式による評価手法は安全側に評価できるものの, 載荷荷重毎に線形固有值解析を行う必要があり計算コストが高い。 そこで，本項では連続体置換法を用いて簡易に座屈荷重係数の評価 を試みる。まず水平荷重による座屈荷重の低下を評価するために, 連続体置換法により逆対称荷重, 台形型荷重下での座屈荷重 ${ }_{A} P_{c r}$ に 対する逆対称 + 水平荷重, 台形 + 水平荷重下での座屈荷重 ${ }_{s} P_{c r}$ の比 ${ }_{S} P_{c r} r_{A} P_{c r}$ を導出する。

ここで, 線形弾性の理論に基づく連続体置換法により弾塑性座屈 荷重の評価を行う準備として, 線形座屈荷重に対する弾塑性座屈荷 重の比 $\alpha_{1}$ （弾塑性座屈荷重の低減係数）を分析する。図 15 に弾塑 性座屈荷重の低減係数 $\alpha_{1}$ を示す。図の横軸は逆対称 (台形型) 荷重 に対する弾塑性座屈荷重の低減係数 ${ }_{A} \alpha_{1}$, 縦軸は逆対称 (台形) + 水 平荷重に対する弾塑性座屈荷重の低減係数 ${ }_{5} \alpha_{1}$ を示す。これらの低 減係数はモデル毎に概漦等しい。これより，水平荷重による幾何学 的非線形および材料非線形性の影響が小さいといえる。また，逆対 称 (台形型) 荷重下に対する逆対称 (台形)+ 水平荷重下での座屈荷 重の比は, 線形固有值解析と弾塑性座屈解析で等しいといえる。こ の関係および線形座屈荷重式 (式 (13)) に基づき座屈荷重の比 ${ }_{s} P_{c r}$ ' ${ }_{A} P_{c r}$ は次式で表される。

$$
\frac{{ }_{S} P_{c r}^{p l}}{{ }_{A} P_{c r}^{p l}} \approx \frac{{ }_{S} P_{c r}^{l i n}}{{ }_{A} P_{c r}^{l i n}}=\frac{1}{1+\left(p_{H \max } / p_{V \max }\right) \sin \theta}
$$

ここに，添え字 lin, pl はそれぞれ線形および弾塑性を表す。

ここで, 式(17)の有効性について分析するために, 図 16 に逆対称 荷重下での座屈荷重に対する逆対称 + 水平荷重下での座屈荷重の 比 ${ }_{S} P_{c r} /{ }_{A} P_{c r}$ と, 台形型荷重下での座屈荷重に対する台形 + 水平荷
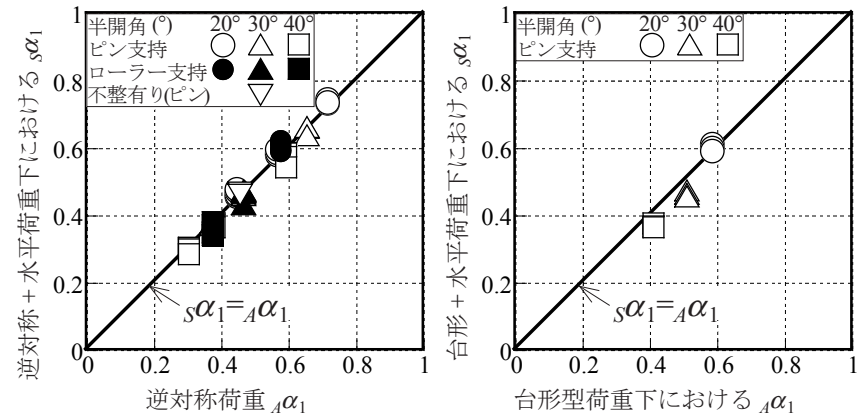

(A) 逆対称 + 水平荷重下における $\alpha$

台形型荷重下における ${ }_{A} \alpha_{1}$ 図 15 弾塑性座屈荷重の低減係数 $\alpha_{1}$

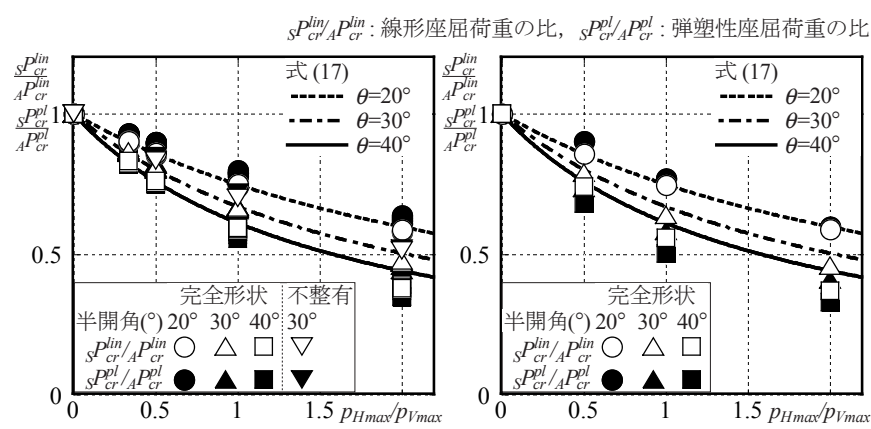

(A) 逆対称+水平荷重 $\left({ }_{S} P_{c r}^{l i n}{ }_{A} P_{c r}^{l i n},{ }_{S} P_{c r}^{p l}{ }_{A} P_{c r}^{p l}\right)$ (B) 台形+水平荷重 $\left({ }_{S} P_{c r}^{l i n}{ }_{A} P_{c r}^{l i n},{ }_{S} P_{c r}^{p l}{ }_{A} P_{c r}^{p l}\right)$ 図 16 座屈荷重の比 ${ }_{S} P_{c r}^{l i n}{ }_{A} P_{c r}^{l i n},{ }_{S} P_{c r}^{p l} / P_{A} P_{C r}^{p l}$

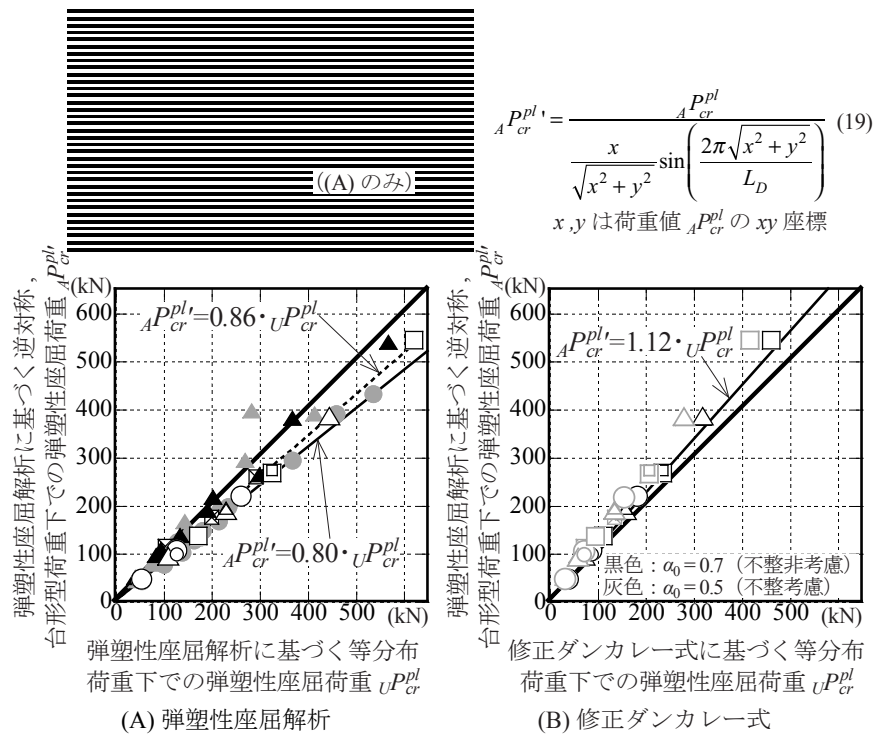

図 17 弾塑性座屈荷重の関係 ${ }_{U} P_{C r}^{p l},{ }_{A} P_{C r}^{p l !}$

重下での座屈荷重の比 ${ }_{S} P_{c r}{ }_{A} P_{c r}$ を示し, 座屈解析值と式 (17) の対応 関係を分析する。式 (17) は座屈解析による線形および弾塑性座屈 荷重の比と概ね良い対応を示す。

このように式 (17) の右の等号も解析結果を評価できているため, 固定荷重に対する弾塑性座屈荷重の荷重係数 $\eta_{U}\left(={ }_{U} P_{r r}^{p l} / m g\right)$ と静的 地震荷重に対する弾塑性座屈荷重の荷重係数 $\eta_{S}\left(={ }_{A} P_{c r}^{p l} / m A_{e q} F_{V}\right)$ の比 は式 (17)を用いると次式のように展開される。

$$
\begin{aligned}
\frac{\eta_{S}}{\eta_{U}} & =\frac{{ }_{S} P_{c r}^{p l}}{m A_{e q} F_{V}} \cdot \frac{m g}{{ }_{U} P_{c r}^{p l}} \\
& =\frac{{ }_{A} P_{c r}^{p l},}{{ }_{U} P_{c r}^{p l}} \cdot \frac{1}{1+\left(p_{H \max } / p_{V \max }\right) \sin \theta} \cdot \frac{g}{A_{e q} F_{V}}
\end{aligned}
$$

ここに, ${ }_{A} P_{c r}^{p l},{ }_{S} P_{c r}^{p l}$ は節点 N2 の荷重值を用いて式 (19)により算出し 
た $x y$ 座標 $(-L / 4,0)$ における逆対称荷重および逆対称 +水平荷重下で の弾塑性座屈荷重である。分布荷重の最大值の比 $p_{H \max } / p_{V \max }$ は表 4 に示すように応答増幅率の比 $F_{H} / F_{V}$ と同值である。

式(18)の未知数である ${ }_{A} P_{c r}^{p l}{ }_{U} P_{c r}^{p l}$ の值を分析するために, 図 17 に等 分布荷重に対する弾塑性座屈荷重 ${ }_{U} P_{c r}^{p l}$ と, 逆対称荷重および台形 型荷重に対する弾塑性座屈荷重 ${ }_{A} P_{c r}^{p l r}$ の関係を示す。ここで, (A) で は, 等分布荷重下での弾塑性座屈荷重を弾塑性座屈解析より求め, (B) では, 線形座屈荷重式 (式 (13)) および修正ダンカレー式 (式 (16)) を用いて算出する。この (B) において修正ダンカレー式を用いるに あたりノックダウンファクター $\alpha_{0}$ には, 本研究の結果（図 14）が示 すように初期不整を考慮していない 0.7 と，文献 2)に示されている ように初期不整を考慮した 0.5 を用いる。また，逆対称荷重下にお ける ${ }_{A} P_{C r}^{p l}$ は式 (19) に節点 N2 における鉛直方向の荷重值を代入す ることにより算出する。なお，(A) には 3 方向グリッドドームにお ける弾塑性座屈荷重 ${ }^{13)}$ を併せて示寸。図より, 等分布荷重と逆対 称荷重下での弾塑性座屈荷重の関倸は半開角によらず概ね比例関係 にあることがわかる。そこで完全形状のピン支持のみを対象に同関 係を最小二乗法により表すと, 弾塑性座屈解析の結果 (A) に対して は ${ }_{A} P_{c r}^{p l}=0.86 \cdot{ }_{U} P_{c r}^{p l}$ となる。また, 下限值は, 弾塑性座屈解析の結果 (A) に対しては ${ }_{A} P_{c r}^{p l \prime}=0.80 \cdot{ }_{U} P_{c r}^{p l}$ で, 修正ダンカレー式の結果 (B) に対し ては ${ }_{A} P_{c r}^{p l}=1.12 \cdot{ }_{U} P_{c r}^{p l}$ で表すことができる。なお，台形型荷重下のプ ロットはこの下限值付近に得られる。ローラー支持モデルおよび初 期不整を有するモデルにおいてもこの下限值より評価できる。3 方 向グリッドドーム ${ }^{13)}$ においてはピン支持でラチス材が断面設計さ
れたモデルにおいてこの下限值を下回ることがあるが，概ね上側に プロットされる。以上より, 評価式 (18) と ${ }_{A} P_{c r}^{p l 1}{ }_{U} P_{c r}^{p l}$ の下限值であ る 0.80 程度 (弾塑性座屈解析) および 1.12 程度 (修正ダンカレー式) を用いることで静的地震荷重に対する座屈耐力の下限が得られると いえる。

\section{6. 単層ラチスドームの動的座屈性状}

本章では, 本研究で採用した静的地震荷重 (表 4) を質量で除し た応答加速度と動的応答解析による応答加速度について分析すると ともに, 式(18) の有効性について分析する。ここでは, 屋根部に おいて逆対称 1 波型の振動モードが卓越するように，逆対称 1 波型 の振動モードの固有周期に対する等価 1 質点系に置換したモデルの 固有周期の比 $R_{T}$ が 1.0 程度となる下部構造を付加したモデル ( 下部 付加モデル FD) についても検討を行う。なお，下部構造の柱は弾性 とし, 梁は剛とする。固定荷重は構造材重量, 仕上げ材重量, 吊り 荷重等を考慮し, 屋根部では $1.18 \mathrm{kN} / \mathrm{m}^{2}$, 下部構造では $0.98 \mathrm{kN} / \mathrm{m}^{2}$, 及びテンションリングでは自重からなる。下部付加モデルでの振動 に関与寸る屋根部の質量 $M_{R}{ }^{\prime}$ に対する等価 1 質点系の質量の比 $R_{M}$ は 2.1 程度である。

\section{1 . 地震応答特性}

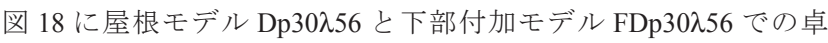
越振動モードを示す。屋根モデルでは高次のモードが卓越し，逆 対称 1 波型の振動モードの有効質量比が小さい。一方, 下部付加 モデルでは屋根部が逆対称 1 波型の振動モードとスウェイを伴う

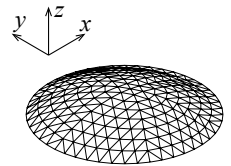

170 th $55.7 \% 0.087 \mathrm{~s}$ 有効質量比 固有周期

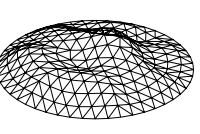

(A) 屋根モデル, Dp $30 \lambda 56$
. $0.361 \mathrm{~s} 172 \mathrm{nd} 5.6 \%$

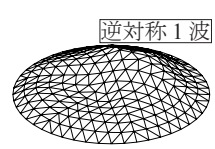

1 st $4.3 \% 0.391 \mathrm{~s}$ $18 \times$ 方向の卓越

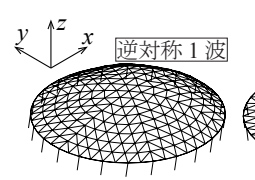

1 st $76.8 \% 0.447 \mathrm{~s}$
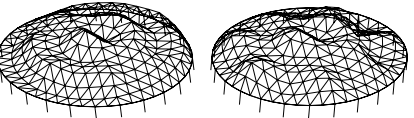

37 th $\quad 6.0 \% 0.274 \mathrm{~s} \quad 24$ th $\quad 5.6 \% 0.305 \mathrm{~s}$ 2nd $4.1 \% 0.383 \mathrm{~s}$ (B) 下部付加モデル, $F D p 30 \lambda 56$

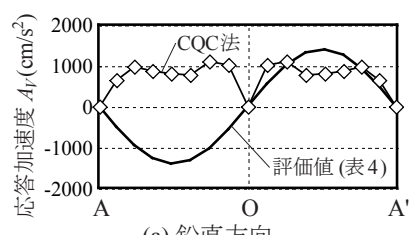

(a) 鉛直方向

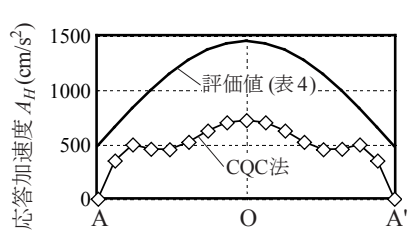

(b) 水平方向

(A) 屋根モデル，Dp30入56

図 19 最大応答加速度分布（稜線 $A O A^{\prime}$ 上）

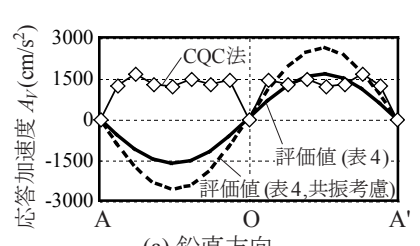

(a) 鉛直方向

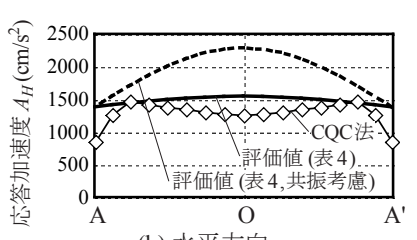

(b) 水平方向

(B) 下部付加モデル，FDp30 2056

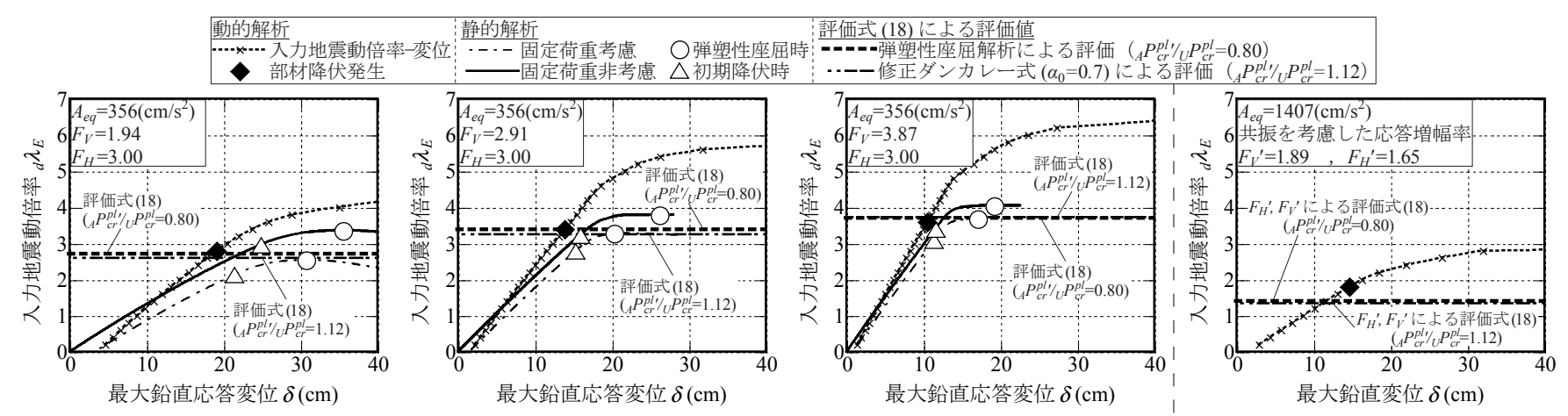

(A2) 屋根モデル，Dp30 256

図 20 入力地震動倍率 - 最大鉛直応答変位
(B1) 下部付加モデル, FDp30 256 
振動モードが卓越する。図 19 に CQC 法による最大応答加速度分布 を示す。CQC 法で採用する振動モードは $x$ 方向の有効質量比の和 が $90 \%$ 以上となるよう採用する ${ }^{14-15)}$ 。入力地震波の応答スペクト ルには BRI-L2 ${ }^{31-32)}$ を用いる。図中には表 4 に示す応答加速度の評 価值を併せて示す。屋根モデルおよび下部付加モデルでの鉛直応答 加速度は節点 $\mathrm{O}$ でほぼ 0 であり, 節点 $\mathrm{O}$ を軸に左右対称の文献 16) で提案されている台形状に近い分布となる。屋根モデルにおいて, 評価值は水平方向で過大評価となるものの，鉛直方向では概水の節 点において安全側に評価できている。このため, 逆対称+水平荷重 下では最大応答変位を安全側に評価できると考えられる。また，下 部付加モデルの鉛直方向の最大応答加速度は共振を考慮した評価值 が若干過大評価となるものの, 評価值と概㸚良い対応を示す。

\section{2. 動的増分解析による動的座屈耐力}

最後に, 入力地震動強さを変化させて時刻歴応答解析を行うこと で評価式 (18) の有効性について分析を行う。BCJ-L2 の原波を入力 地震動倍率 ${ }_{d} \lambda_{E}=1$ と定義し, この倍率により入力地震動強さを変 化させて解析を行う (動的増分解析)。図 20 に動的増分解析による 入力地震動倍率一最大鉛直応答変位関係を示寸。屋根モデルにおい ては静的地震荷重に比例した分布荷重に対する弾塑性座屈解析によ る推移を併せて示す。静的解析による入力地震動倍率は次式に示寸 ように静的地震荷重に対する荷重係数として換算する。

$$
{ }_{d} \lambda_{E}=\left(P-{ }_{D} P_{0}\right) /{ }_{S} P_{0}
$$

ここに, $P$ は参照節点における載荷荷重, ${ }_{D} P_{0}$ は固定荷重, ${ }_{S} P_{0}$ は静 的地震荷重である。

図中には評価式 (18)により算出した座屈荷重係数を併せて示す。 なお, 固定荷重に対する弾塑性座屈荷重の荷重係数 $\eta_{U}$ を弾塑性座 屈解析より算出した場合は ${ }_{A} P_{c r}^{p l} /{ }_{U} P_{c r}^{p l}=0.80$ とし, $\eta_{U}$ を線形座屈荷重 式(13) および修正ダンカレー式 (16) を用いて算出した場合は ${ }_{A} P_{c r}^{p l \mid}$ ${ }_{U} P_{c r}^{p l}=1.12$ とする。ただし, ここでは初期不整を考慮していないため, ノックダウンファクター $\alpha_{0}$ は 0.7 とする。屋根モデルにおいては, 動的解析における入力地震動倍率一変位関係と静的解析における荷 重一変位関係の初期降伏までの勾配は概ね等しく, 動的解析におけ る部材降伏発生時と静的解析における初期降伏時も概称等しい。詳 細に比較すると, 動的解析における入力地震動倍率-变位関係に比 べ静的解析における荷重一変位関係の勾配は若干小さく, 最大応答 変位を安全側に評価可能であるといえる。また, 評価式 (18) によ る值は, 部材降伏が発生した入力地震動倍率と同程度となり, 静的 解析における弾塑性座屈荷重を安全側に評価できている。なお, 図 には修正ダンカレー式を用いた評価式 (18) $\left({ }_{A} P_{c r}^{p l_{1}} P_{c r}^{p l}=1.12\right)$ とし てノックダウンファクター $\alpha_{0}$ を 0.7 とした場合を示しているが， $\alpha_{0}$ を 0.5 として評価式 (18) $\left({ }_{A} P_{c r}^{p l 1} / U P_{c r}^{p l}=1.12\right)$ を算出することで初期不 整を考慮したことになり，より安全側に評価することができる。ま た，固定荷重を考慮した場合には，固定荷重を考慮していない場合 に比べ初期降伏および弾塑性座屈荷重が低下し, 評価式 (18) によ る弾塑性座屈荷重の評価は若干危険側となる。このため, 評価式 (18) に固定荷重の影響を考慮することが今後の課題となる。下部付加モ デルにおいても，下部と屋根部の共振を考慮した応答増幅率を用い ると, 評価値に比べ動的解析よる部材降伏が発生した入力地震動倍 率が大きい。これより, 評価式 (18) は地震荷重に対する耐力の下 限をとらえることができるといえる。

\section{7. 結論}

本研究では半開角 $40^{\circ}$ 以下の単層ラチスドームを対象とし, 静的 地震荷重に対する座屈耐力を明らかにすることを目的とし，正弦 波 1 波型の分布荷重（逆対称荷重）または台形型の分布荷重（台形 型荷重）と水平荷重を同時に受ける場合の座屈荷重について分析し た。また，連続体置換法により座屈荷重係数を評価することで，時 刻歷応答解析を用いない地震荷重に対する耐力評価手法を提案し た。さらに, 座屈荷重係数による評価式の有効性を動的増分解析を 行うことで示した。以下に得られた知見を示す。

1) 静的地震荷重に比例した分布荷重を受ける場合，鉛直方向の荷重 が最大となる節点における線形座屈荷重は連続体置換法により 評価できる。また，線形座屈荷重に対する弾塑性座屈荷重の比は 逆対称荷重下と同程度である。そのため, 逆対称荷重下における 弾塑性座屈荷重に対する静的地震荷重に比例した分布荷重を受 ける時の弾塑性座屈荷重の比は連続体置換法により評価できる。

2) 等分布荷重, 逆対称荷重と水平荷重, 台形型荷重と水平荷重下 における弾塑性座屈荷重は線形座屈荷重に対する弾性座屈荷重 の比であるノックダウンファクターを用いた修正ダンカレー式 により安全側に評価できる。ただし, 評価に用いたノックダウン ファクターは，ピン支持，ローラー支持の両場合ともに，等分布 荷重下で 0.7 , その他の分布荷重下で 0.6 である。なお, ローラー 支持の場合，等分布荷重下でのノックダウンファクターは 0.5 程 度であるものの，ピン支持同様に 0.7 で安全側に評価可能である。

3) 等分布荷重下での弾塑性座屈荷重 ${ }_{U} P_{c r}^{p l}$ と逆対称荷重下での弾塑 性座屈荷重 ${ }_{A} P_{c r}^{p l r}$ は半開角によらず比例関係にあり, ${ }_{A} P_{c r}^{p l} /{ }_{U} P_{c r}^{p l}$ の 下限は等分布荷重下での弾塑性座屈荷重を弾塑性座屈解析によ り求めた場合 0.80 程度であり, 修正ダンカレー式により求めた 場合には 1.12 程度である。この下限值に加え連続体置換法を援 用することで静的地震荷重に対する座屈耐力を固定荷重に対す る座屈耐力より評価でき, この評価の有効性を動的増分解析によ り確認した。

このように本研究の分析により，鉛直等分布荷重と静的地震荷重 下の座屈性状の関係が明らかとなった。しかし本研究では, 地震時 の上界になると考えられる座屈荷重をとらえ，鉛直等分布荷重に対 する座屈性状との比較を行うことを主目的としたために, 固定荷重 の影響は考慮していない。このため, 座屈評価式の誘導は固定荷重 を考慮せずに行っている。また, 固定荷重の影響は, 固定荷重を考 慮して静的地震荷重を扱った加藤・中澤らによる研究 ${ }^{11-12)}$ との比 較と 6.2 節の動的座屈解析時においてのみでしか分析していない。 しかし，地震時の固定荷重の影響を分析することも設計上重要であ り，固定荷重を考慮した状態における静的地震荷重に対する同様の 評価は今後の課題である。

\section{参考文献}

1) 日本建築学会シェル空間構造運営委員会 : 単層ラチスドームの安定解析 一その現状と問題点-, 日本建築学会, 1989.9

2) 日本建築学会 : ラチスシェルの座屈と耐力, 丸善, 2010.6

3) 日本建築学会 : 鋼構造物の座屈に関する諸問題 2013, 13 章, 丸善, 2013.6 4) 熊谷知彦, 谷口与史也, 小河利行, 舟橋靖之: 網目形状および境界条件の 
異なる二層立体ラチスドームの弾塑性座屈性状および而力評価, 構造工学 論文集，Vol.54B，pp.337-344，2008.3

5) 小河利行，熊谷知彦，小林晃子，重田幸乃，加藤史郎：等分布荷重およ び偏載荷重を受ける鞍型 HP ラチスシェルの耐力評価, 構造工学論文集, Vol.59B, pp.455-462, 2013.3

6) 加藤史郎, 庄村昌明, 向山洋一：水平と鉛直地震動を受ける大スパン単層 ラチスドームの応答性状と崩壊加速度に関する研究, 日本建築学会構造系 論文集，第 477 号，pp.87-96，1995.11

7) 村田 賢：上下および水平地震動を受ける単層ラチスドームの動特性につ いて, 日本建築学会構造系論文集, 第 571 号, pp.103-110, 2003.9

8) 加藤史郎, 村田 賢, 佐藤俊樹, 庄村昌明 : ステップ荷重を受ける単層ラ チスドームの動座屈，日本建築学会構造系論文集，第 494 号，pp.67-74， 1997.4

9) 熊谷知彦, 小河利行: 水平方向単一パルス波を受ける単層ラチスドーム の動的座屈性状, 日本建築学会構造系論文集, 第 585 号, pp.115-122, 2004.11

10) S.Nakazawa, N.Takahashi, S.Kato : Evaluation of Seismic Performance for Single Layer Reticular Domes based on Static Analysis, Proceedings of the IASS Symposium 2013, Wroclaw, Paper ID 1209 (CD-ROM), 2013.9

11) 高橋直生, 中澤祥二, 加藤史郎 : 静的地震荷重を用いた単層ラチスドーム の耐震性能評価に関する研究 その 1 静的地震荷重に対する耐荷性能, 日本 建築学会大会学術講演梗概集, 構造 I, pp.909-910, 2013.8

12) 中澤祥二, 加藤史郎, 高橋直生 : 静的地震荷重を用いた単層ラチスドーム の耐震性能評価に関する研究 その 2 耐震性能評価の推定, 日本建築学会大 会学術講演梗概集，構造 I, pp.911-912，2013.8

13) 小河利行, 竹内 徹, 熊谷知彦, 山岡幸介 : 逆対称荷重を受ける単層ラチ スドームの座屈荷重，構造工学論文集，Vol.59B，pp.463-469，2013.3

14) 竹内 徹, 小河利行, 中川美香, 熊谷知彦：応答スペクトル法による中規 模ラチスドームの地震応答評価, 日本建築学会構造系論文集, 第 579 号, pp.71-78, 2004.5

15) 竹内 徹, 熊谷知彦, 調 浩朗, 小河利行:多層架構で支持されたラチスシェ ル構造の地震応答評価, 日本建築学会構造系論文集, 第 619 号, pp.97-104, 2007.9

16) T.Yanagisawa, S.Nakazawa, S.Kato : Proposal of Seismic Loads for Single Layer Reticular Domes, Proceedings of the IASS Symposium 2013, Wroclaw, Paper ID 1250 (CD-ROM)， 2013.9

17) 坪井善勝 : ガウス曲率とシェルの座屈 $\mathrm{I}$-膜応力状態からの座屈-, 日本建 築学会論文報告集，第 230 号, pp.37-42, 1975.4

18) 加藤史郎，山下哲郎，柴田良一 : 連続体近似法による 2 方向格子シェルの
座屈耐力評価, 構造工学論文集，Vol.46B，pp.167-174，2000.3

19) S.Kato and T.Yamashita : Evaluation of Elasto-plastic Buckling Strength of Two-way Grid Shells using Continuum Analogy, International Journal of Space Structures, Vol.17 No.4, 2002.12

20) 山下哲郎, 加藤史郎 : 連続体近似に基づくブレース補剛単層 2 方向格子シェ ルの弾性座屈特性の評価, 構造工学論文集, Vol.54B，pp.331-336，2008.3

21) 山田聖志 : 単層円筒ラチスの座屈現象分析とその設計への利用, 構造工学 論文集，Vol.56B，pp.507-515，2010.3

22) 小河利行，熊谷知彦，車 創太，箕輪健一：鉛直分布荷重を受ける鞍型 HP ラチスシェルの弾性および弾塑性座屈荷重, 日本建築学会構造系論文集, 第 660 号, pp.337-346, 2011.2

23) T. Ogawa, T. Kumagai, K. Minowa, S. Kato : Buckling Load of Saddle-shaped HP Reticulated Shells, Journal of the International Association for Shell and Spatial Structures, Vol.53 No.1, pp.57-67, 2012.3

24) 加藤史郎, 庄村昌明, 柴田良一, 植木隆司: 円形平面を有する単層ラチスドー 厶の座屈荷重の推定, 日本建築学会構造系論文報告集, 第 439 号, pp.111$119, \quad 1992.9$

25) 日本建築学会 空間骨組小委員会二層立体ラチス構造研究班 : 二層立体ラチ ス構造の解析・設計・施工-その現状と問題点-, 日本建築学会, 1992.11

26) T. Suzuki, T. Ogawa, K. Ikarashi : Elasto-Plastic Buckling Analysis of Rigidly Jointed Single Layer Reticulated Domes, International Journal of Space Structures, Vol.7 No.4, pp.249-261, 1992

27) 鈴木敏郎, 小河利行, 久保寺勲, 五十嵐規矩夫:ボール接合単層ラチスドー ムの座屈実験及び弾塑性座屈解析 中央集中荷重を受ける部分球形ドームに ついて，日本建築学会構造系論文報告集，第444 号, pp.53-62, 1993.2

28) 日置興一郎 : 構造力学 II, 朝倉書店, 1977.11

29) 中澤祥二, 加藤史郎, 八木佑奈 : 単層ラチスドームの地震時の損傷評価方 法に関寸る基礎的研究，日本建築学会構造系論文集，第 674 号，pp.593$601,2012.4$

30) 中澤祥二，高橋直生，加藤史郎：下部構造を有寸る単層ラチスドームの耐 震性能評価に関寸る研究，日本建築学会構造系論文集，第 678 号，pp.799$807,2013.4$

31) 建設省建築研究所: 建築研究資料第 83 号 設計用入力地震動作成手法, 1994.11

32) 笠井和彦, 伊藤浩資, 渡辺 厚 : 等価線形化手法による一質点弾塑性構 造の最大応答予測法, 日本建築学会構造系論文集，第 571 号，pp.53-62, 2003.9

33) 坪井善勝 : 曲面構造 シェルの理論とその応用, 丸善, 1965.3 


\title{
BUCKLING STRENGTH OF SINGLE LAYER LATTICE DOMES UNDER STATIC SEISMIC LOAD
}

\author{
Toshiyuki OGAWA* ${ }^{1}$, Kousuke YAMAOKA ${ }^{* 2}$, Ken'ichi MINOWA*3 \\ and Toru TAKEUCHI*4 \\ ${ }^{*}$ Prof., Dept. of Arch. and Building Eng., Tokyo Institute of Technology, Dr. Eng. \\ * 2 Former Graduate Student, Dept. of Arch. and Building Eng., Tokyo Institute of Technology, M. Eng. \\ *3 Assist. Prof., Dept. of Arch. and Building Eng., Tokyo Institute of Technology, Dr. Eng. \\ ${ }^{* 4}$ Prof., Dept. of Arch. and Building Eng., Tokyo Institute of Technology, Dr. Eng.
}

\section{Introduction}

Although large numbers of attempts have been made to evaluate buckling strength of single layer lattice domes under equally-distributed vertical loads, stability under seismic loads has not been studied enough yet. In this paper, evaluation method on buckling strength of single layer lattice domes based on continuum shell analogy under equivalent static seismic loads proposed in the previous studies is investigated. First, the buckling behavior under distributed loads proportional to the static seismic loads is researched taking shape parameters into account. Next, the buckling strength for vertical loads and the buckling strength for static seismic loads is evaluated using continuum shell analogy, and converted to elastoplastic buckling strength using knockdown factors and Dunkerley formulation. The effectiveness of the proposed evaluation is discussed against the results of time-history response analyses.

\section{Analysis models and numerical static analyses}

The studied models are single layer parallel lamella domes with $80 \mathrm{~m}$ span and half subtended angles of 20, 30, 40 degrees. The slenderness ratios of the lattice members are set as 42, 56, 79 respectively, and static buckling analyses and dynamic response analyses were carried out on these models. Load distributions for the static analysis are set as uniformly-distributed vertical loading or equivalent seismic loading combining anti-symmetrically and horizontally distributed loadings proposed by authors.

\section{Buckling strength under different horizontal loads}

The horizontal component in the proposed seismic loads varies depending on horizontal amplitude factor $F_{H}$. The effect of the horizontal component on the buckling strength is discussed based on the above static analyses.

\section{Theoretical buckling loads under equivalent static seismic loads}

To evaluate the theoretical buckling strength under seismic loading, the equations for the linear buckling strength under anti-symmetrical loads and horizontal loads are derived based on the continuum shell analogy and combined to express the various loading proportions. The obtained linear buckling strengths are compared with the elastic buckling strength by numerical analyses including geometrical non-linearity, and knockdown factors to express these effects are evaluated.

\section{Evaluation of elasto-plastic buckling strength}

Evaluation methods of elasto-plastic buckling strength under the equivalent seismic loads are proposed using Dunkerley formulation on the obtained elastic buckling strength. Further, another simple evaluation method converting the buckling strength under the vertical loads to the buckling strength under the equivalent seismic loads are proposed.

\section{Dynamic buckling strength compared with the proposed methods}

In order to confirm the validity of the proposed evaluation method, incremental dynamic analyses (IDA) using an artificial seismic wave BCJ-L2 are conducted. The dynamic buckling strengths obtained by the numerical analyses are compared with those by the proposed method, and their validity is discussed.

\section{Conclusions}

By above studies, the following results are obtained.

1) The theoretical linear buckling strength under equivalent seismic loads can be derived using continuum shell analogy, by combining the buckling strength under anti-symmetrical loads and horizontal loads.

2) The elasto-plastic buckling strength under equivalent seismic can be evaluated from the theoretical linear buckling strength using the knockdown factors and Dunkerley formulation.

3) The elasto-plastic buckling loads under uniformly distributed loads and anti-symmetric loads are confirmed to have a proportional relationship. Consequently, buckling strength under the equivalent static seismic loads can be evaluated from the buckling strength under the equally-distributed vertical loads using continuum shell analogy. The validity of the proposed evaluation method was confirmed by IDA analyses including geometrical and material non-linearity. 